\section{Silicon Fertilization Affects Growth of Hybrid Phalaenopsis Orchid Liners}

\author{
Wagner A. Vendrame ${ }^{1,4}$, Aaron J. Palmateer ${ }^{1}$, Ania Pinares ${ }^{1}$, \\ Kimberly A. Moore ${ }^{2}$, and Lawrence E. Datnoff ${ }^{3}$
}

ADDITIONAL INDEX WORDS. seedlings, nutrition, floriculture

Summary. Experiments were conducted during two different time periods to determine if hybrid phalaenopsis orchid (Phalaenopsis spp.) liners accumulate silicon $(\mathrm{Si})$ and if this element can affect liner growth. A total of 800 liners were evaluated and $\mathrm{Si}$ fertilization was performed by applying potassium silicate $\left(\mathrm{KSiO}_{3}\right)$ as a drench with three treatments $(0.5 \%, 1.0 \%$, and $2.0 \% \mathrm{v} / \mathrm{v})$ and a control (water, no $\mathrm{Si}$ fertilization). The application of $\mathrm{KSiO}_{3}$ affected overall growth of phalaenopsis orchid liners, where Si content of the plant ranged from $0.5 \%$ to $1.7 \%$. Overall, Si applied at $\mathbf{0 . 5 \%}$ and $\mathbf{1 . 0 \%}$ increased fresh weight and dry weight (DW) and at $1.0 \%$ Si significantly increased DW of root, shoot, and whole plant over the control. Increases in DW ranged from $27 \%$ up to $118 \%$. Results from the second experiment were similar. Other plant parameters evaluated such as leaf number and size, root number, and length were unaffected by Si application. Although leaves of phalaenopsis orchid liners treated with $\mathrm{Si}$ appeared darker green when compared with the control, no significant differences were observed in chlorophyll content of leaves. Reduced growth was observed when $2.0 \% \mathrm{Si}$ was applied affecting Si tissue concentrations and substrate electric conductivity. The data obtained from this study indicate that hybrid phalaenopsis orchid liners are $\mathrm{Si}$ accumulators and that this element influences their growth. Further studies are warranted to address the long-term effects of Si fertilization on the complete life cycle of hybrid phalaenopsis orchids.

S ilicon $(\mathrm{Si})$ is the second most abundant element in soil (Epstein, 1999) and its function in plants still represents a subject for continued research (Raven, 2003). A recent study demonstrated that $\mathrm{Si}$ plays a role in enhancing the growth and appearance of flowering ornamentals. Silicon fertilization enhanced shoot number, flower number, and dry weight by $25 \%, 62 \%$, and $66 \%$, respectively, over controls for paper daisies (Helichrysum adenohorum) (Muir et al., 1999). Thicker flower stems and a higher proportion of flowers graded Class I were observed in gerbera (Gerbera jamesonii) when using $35.1 \mathrm{mg} \cdot \mathrm{L}^{-1} \mathrm{Si}$ (Savvas et al., 2002). Similarly, Kamenidou

This study was funded by the Florida Nurserymen, Growers, and Landscape Association (FNGLA) through the FNGLA Endowed Research Fund.

We thank Kerry Herndon and Robert McMillan for providing us with plant material and nursery space for this experiment.

${ }^{1}$ University of Florida, Tropical Research and Education Center, IFAS, 18905 SW 280th Street, Homestead, FL 33031-3314

${ }^{2}$ University of Florida, Ft. Lauderdale Research and Education Center, IFAS, 3205 College Avenue, Davie, FL 33314

${ }^{3}$ Louisiana State University, Department of Plant Pathology and Crop Physiology, 306 Life Sciences, Baton Rouge, LA 70803

${ }^{4}$ Corresponding author. E-mail: vendrame@ufl.edu. et al. (2010) reported taller flowers and larger flower diameters in gerbera when sodium silicate foliar sprays were applied at 50 to $100 \mathrm{mg} \cdot \mathrm{L}^{-1}$ and peduncles with increased basal and apical diameters when potassium silicate $\left(\mathrm{KSiO}_{3}\right)$ drenches were applied at $200 \mathrm{mg} \cdot \mathrm{L}^{-1}$. Dry weight increases of $6 \%$ to $80 \%$ were also observed in several ornamental plants when $\mathrm{Si}$ was applied as $\mathrm{KSiO}_{3}$ at $47 \mathrm{mg} \cdot \mathrm{L}^{-1}$ (Chen et al., 2000b, 2000c, 2001). Greater leaf thickness was also observed compared with the control. Thick, straight stems, increased flower and stem diameters, and increased height have been reported in ornamental sunflower (Helianthus annuus 'Ring of Fire'), improving quality (Kamenidou et al., 2008). Similarly, variable responses were reported for several floriculture crops, whereby $\mathrm{Si}$ supplementation affected plant height, diameter, fresh weight, dry weight, flower diameter, and leaf thickness (Mattson and Leatherwood, 2010).

Other benefits of $\mathrm{Si}$ for crops reported in the literature include disease and insect control, decrease in mineral toxicity concentrations, freeze alleviation, water-use efficiency, improved crop quality and yield (Datnoff et al., 2001; Richmond and Sussman, 2003); and salinity (Epstein, 1999), heavy metal (Neumann and zur Nieden, 2001), and drought (Lux et al., 2002) tolerance.

Among ornamental plants, orchid production has increased over the past 10 years as a result of their popularity, the rapid expansion of the market, and the interest of growers and customers for new and improved hybrids. By 2004, orchids ranked second among potted floriculture crops in the United States with wholesale revenues estimated at $\$ 128$ million [U.S. Department of Agriculture (USDA), 2005]. Orchid production reached $8 \%$ of the global floriculture trade by 2006 (Martin and Madassery, 2006). In 2005, wholesale numbers added to 18 million potted orchids sold in the United States (USDA, 2006). Phalaenopsis orchids are the most popular potted orchids sold (USDA, 2006) as a result of their short cycle and large hybrid numbers with variety of flower colors and patterns as well as number of flowers and long duration of flowering period. In Holland, potted phalaenopsis orchids are highly valuable and in 2006, wholesale revenues of 173.7 million Euros were reported (Vereniging van Bloemenveilingen in Nederland, 2007).

A previous study used light and electron microscopy to detect Si accumulation in phalaenopsis orchids (Zhou, 1995). Results indicated that the growth of the silica bodies increased by increasing the concentration

\begin{tabular}{llll}
\hline $\begin{array}{l}\text { Units } \\
\begin{array}{l}\text { To convert U.S. to SI, } \\
\text { multiply by }\end{array}\end{array}$ & U.S. unit & SI unit & $\begin{array}{l}\text { To convert SI to U.S., } \\
\text { multiply by }\end{array}$ \\
\hline 29.5735 & $\mathrm{fl} \mathrm{oz}$ & $\mathrm{mL}$ & 0.0338 \\
3.7854 & gal & $\mathrm{L}$ & 0.2642 \\
2.54 & inch $(\mathrm{es})$ & $\mathrm{cm}$ & 0.3937 \\
1 & $\mathrm{mmho} / \mathrm{cm}$ & $\mathrm{dS} \cdot \mathrm{m}^{-1}$ & 1 \\
28.3495 & $\mathrm{oz}$ & $\mathrm{g}$ & 0.0353 \\
28,350 & $\mathrm{oz}$ & $\mathrm{mg}$ & $3.5274 \times 10^{-5}$ \\
1 & $\mathrm{ppm}$ & $\mathrm{mg} \cdot \mathrm{L}^{-1}$ & 1 \\
$\left({ }^{\circ} \mathrm{F}-32\right) \div 1.8$ & ${ }^{\circ} \mathrm{F}$ & ${ }^{\circ} \mathrm{C}$ & $\left(1.8 \times{ }^{\circ} \mathrm{C}\right)+32$
\end{tabular}


of calcium silicate $\left(\mathrm{CaSiO}_{3}\right)$. The objective of this study was to evaluate the use of three rates of supplemental $\mathrm{Si}$ fertilizer on the growth of phalaenopsis orchid liners in a large-scale orchid production nursery. Silicon concentrations were measured to verify that phalaenopsis orchid liners are $\mathrm{Si}$ accumulators and if $\mathrm{Si}$ accumulation can be detrimental to liners.

\section{Material and methods}

Plant material. Phalaenopsis orchid liners $(7.5$ to $10.0 \mathrm{~cm}$ in size $)$ growing in 50 -cell plug trays $(50$ liners per tray) containing sphagnum moss as the substrate were selected as plant material. Two experiments were conducted. The first was performed between Apr. and June 2007 with a second replicated experiment between Jan. and Mar. 2008. A total of 16 trays (800 liners) from a commercial nursery was randomly selected for each experiment. Liners were maintained at an average relative humidity of $62.5 \%$ day $/ 85.4 \%$ night and an average light intensity of 150 $\mu \mathrm{mol} \cdot \mathrm{m}^{-2} \cdot \mathrm{s}^{-1}$ photosynthetic photon flux under $55 \%$ shade and natural day length for each experiment period. The average temperature for the first experiment was $29.2 / 21.7^{\circ} \mathrm{C}$ day/ night, whereas for the second experiment, the average temperature was $26.4 / 13.8^{\circ} \mathrm{C}$ day/night. Liner trays were irrigated once per week for 12 weeks at a rate of $2.95 \mathrm{~L} \cdot \mathrm{min}^{-1}$ for $\approx 20$ min per irrigation cycle using the nursery's reverse osmosis water system as the irrigation water source. Irrigation and fertilization were performed at the same time by drenching trays. All trays were fertilized with $150 \mathrm{mg} \cdot \mathrm{L}^{-1}$ of nitrogen $(\mathrm{N})$ per irrigation event as $20 \mathrm{~N}-8.7 \mathrm{P}-16.6 \mathrm{~K}$ (Peters 20-20-20; J.R. Peters, Allentown, PA).

Silicon treatments. Silicon was applied as $\mathrm{KSiO}_{3}$ from PQ Corp. (Valley Forge, PA) consisting of 8.3\% potassium oxide $\left(\mathrm{K}_{2} \mathrm{O}\right), 20.8 \%$ silicon dioxide $\left(\mathrm{SiO}_{2}\right), 70.9 \%$ water, $\mathrm{pH}$ 11.3, in which $\mathrm{SiO}_{2}$ is the a.i. On the days when fertigation was applied to the plants in the morning, $\mathrm{KSiO}_{3}$ drenches $(\mathrm{v} / \mathrm{v})$ were applied in the afternoon for 4 weeks. Treatments performed in both experiments included: 1) no Si fertilization (water control); 2) $0.5 \% \mathrm{Si} ; 3) 1.0 \% \mathrm{Si}$ (general commercial recommended dose); and 4$) 2.0 \% \mathrm{Si}$. For the control, only water was applied using reverse osmosis water at the same rate as described previously. Trays containing 50 phalaenopsis orchid liners were labeled for each treatment and monitored weekly for overall appearance, health, and growth. Treatments were arranged in a completely randomized design with four trays (200 liners) per treatment.

Substrate and plant tissue ANALYSES. Analyses of the sphagnum substrate and liners were performed for $\mathrm{Si}$ content before the initiation of the experiment. Analysis of sphagnum for $\mathrm{Si}$ was performed at the University of Florida Everglades Research and Education Center Soils Laboratory, Belle Glade. Tissue Si analysis was performed at the University of Florida, Department of Plant Pathology, Gainesville. Sphagnum samples were collected before liners were planted. Sphagnum Si concentrations were determined by the method described by Snyder (1991). Briefly, Si was extracted from medium with $0.5 \mathrm{M}$ acetic acid from a 10:25 medium:extractant $(\mathrm{v} / \mathrm{v})$ mix and determined by a Technicon Auto Analyzer (Seal Analytical, Mequon, WI). Determination of Si content in plant tissue (percent by dry weight) followed procedures by Elliott and Snyder (1991). Briefly, $100 \mathrm{mg}$ of plant tissue (leaf blades dried at $75^{\circ} \mathrm{C}$ for $48 \mathrm{~h}$ ) was mixed with $2 \mathrm{~mL}$ of $50 \%$ hydrogen peroxide $\left(\mathrm{H}_{2} \mathrm{O}_{2}\right)$ and $4.5 \mathrm{~g}$ of $50 \%$ sodium hydroxide $(\mathrm{NaOH})$ in a polyethylene tube. The tubes were covered with loose fitting plastic caps and autoclaved at $138 \mathrm{kPa}$ for $1 \mathrm{~h}$. The contents were then brought to $50 \mathrm{~mL}$ with demineralized water. Silicon was extracted by mixing with $35 \mathrm{~mL}$ of $20 \%$ acetic acid, $10 \mathrm{~mL}$ of ammonium molybdate, $5 \mathrm{~mL}$ of $20 \%$ tartaric acid, and $1 \mathrm{~mL}$ of reducing solution (prepared with sodium sulfite, 1-amino-2naphthol-4-sulfonic acid, and sodium bisulfite). The mixture was allowed to stand for $30 \mathrm{~min}$. Automated colorimetric analysis was then used for determination of tissue $\mathrm{Si}$ content. Substrate $\mathrm{pH}$ and electric conductivity (EC) were measured using the pourthrough method. Briefly, after fertigation, the substrate was drained for 30 min. A saucer was placed under the container and $\approx 100 \mathrm{~mL}$ of distilled water was added to the substrate to allow the collection of $\approx 50 \mathrm{~mL}$ of extract solution. The $\mathrm{pH}$ and $\mathrm{EC}$ of extract samples of substrate solution were measured using a $\mathrm{pH}$ meter (Accumet $\mathrm{AB} 15+$; Fisher Scientific, Pittsburgh, PA) and a portable EC meter (Extech EC400; Extech Instruments, Waltham, MA), respectively.

G R O W T H PARA M E T E R EVALUATIONS AND SILICON ANALYSES. Leaf number and size (length $\times$ width) were evaluated weekly using 25 randomly selected liners per tray per treatment (100 total per treatment). Chlorophyll content was estimated weekly using 10 randomly selected liners per tray per treatment (40 total per treatment). Chlorophyll content was estimated using a chlorophyll meter (Minolta SPAD-502; Konica Minolta Sensing, Osaka, Japan). Root number and length and whole fresh weight $(\mathrm{FW})$ and dry weight (DW) were evaluated at the end of each experiment using 25 randomly selected liners per tray per treatment (100 total per treatment). Root and shoot FW were measured separately. Roots and shoots were oven-dried at $75^{\circ} \mathrm{C}$ for $48 \mathrm{~h}$ and $\mathrm{DW}$ was determined. Concentration (percent) $\mathrm{Si}$ in liner leaf tissue was assessed at the end of the experiment using two randomly selected liners per tray per treatment (eight total per treatment). Silicon analyses of plant tissue were performed at the University of Florida, Department of Plant Pathology, Gainesville, using the procedures described previously for plant tissue analysis.

Statistical analysis. Analysis of variance and regression analyses were performed and treatment means were compared using Fisher's protected least significant difference multiple comparison procedure $(P \leq$ 0.05 ) using SAS (Version 9.1; SAS Institute, Cary, NC).

\section{Results and discussion}

Initial analyses of sphagnum substrate used for growing phalaenopsis orchid liners in trays indicated $\mathrm{Si}$ concentrations of $2 \mathrm{mg} \cdot \mathrm{L}^{-1}$, whereas the $\mathrm{Si}$ concentrations in liner tissues varied from $0.1 \%$ to $0.2 \%$. Large variations in Si content have been long reported among species growing in the same soil (Ma and Takahashi, 2002). In general, the Si content in plant tissues may vary from $0.1 \%$ to 10\% (Epstein, 1999). In this study, the concentrations of $\mathrm{Si}$ found in phalaenopsis orchid tissues before receiving supplemental Si fertilizer were 
found to be extremely low. The average $\mathrm{Si}$ content in liner tissues was $0.18 \%$ for Expt. 1 and $0.14 \%$ for Expt. 2. However, as $\mathrm{Si}$ application increased from $0 \%$ to $2 \%$, the Si content in leaf tissue linearly increased in both experiments [Table 1; Fig. 1A $\left(r^{2}=\right.$ 0.97 and $r^{2}=0.99$, respectively)].

The initial $\mathrm{pH}$ of the substrate was 5.8 and the EC $0.78 \mathrm{dS} \cdot \mathrm{m}^{-1}$. As $\mathrm{Si}$ applications increased from $1 \%$ to $2 \%$, the $\mathrm{pH}$ increased to 6.0 , whereas the EC increased tol.7 dS $\mathrm{m}^{-1}$. Similar EC increases have been reported in foliage plants fertilized with $\mathrm{Si}$ by Chen et al. (2000a).

Silicon can dramatically affect plant growth and development in a number of plant species (Epstein, 1999). The beneficial effects of $\mathrm{Si}$ are usually visible in leaves and stems (Ma et al., 2001). Adatia and Besford (1986) reported darker green and thicker leaves in plants of cucumber (Cucumis satious) amended with $\mathrm{Si}$, whereas Chen et al. (2001) observed greater leaf thickness in Si-responsive ornamental plants. Kamenidou et al. (2008) also reported increased thickness and mechanical strength in stems of ornamental sunflowers. In this study, increasing rates of $\mathrm{Si}$ did not significantly change leaf number and size or root number and length. In both experiments, we observed that liners under $0.5 \%$ and $1.0 \%$ Si fertilization had darker green leaves, but no significant differences were observed in chlorophyll content (data not shown).

However, we did observe an increase in DW or FW for whole plant, shoot, and root as $\mathrm{Si}$ increased from $0 \%$ to $1 \%$ and then decreased at the highest Si treatment rate (2\%) (Fig. 1). Similar results were observed by Mattson and Leatherwood (2010) in bracteantha (Bracteantha bracteata), lobelia (Lobelia erinus), and verbena (Verbena $\times$ bybrida). Likewise, Chen et al. (2001) reported an increase in DW in 32 ornamental species fertilized with $\mathrm{Si}$, including dendrobium orchid (Dendrobium nobile) with an increase in DW of $18 \%$ or higher compared with the control. For the phalaenopsis orchids in our study, increases in DW ranged from $27 \%$ up to $118 \%$ (Table 1 ).

Growth parameters were reduced when Si fertilization increased to $2.0 \%$ Si. Kamenidou et al. (2008) reported that $\mathrm{Si}$ treatments resulting in leaf $\mathrm{Si}$ concentrations above $1.2 \%$ caused flower deformations and stunted growth in sunflower. The conclusion was that the effects of $\mathrm{Si}$ fertilization on container-grown sunflowers can be either positive or negative depending on the Si source and applied concentration. In both experiments, one source of $\mathrm{Si}\left(\mathrm{KSiO}_{3}\right)$ was used and treatments supplemented with $2.0 \%$ Si resulted in leaf tissue Si concentrations of $1.34 \%$ and $1.67 \%$ for Expts.1 and 2, respectively. Although $\mathrm{pH}$ and EC levels measured at the end of each experiment were within normal ranges, the EC of the substrate increased to $1.7 \mathrm{dS} \cdot \mathrm{m}^{-1}$ when $2.0 \% \mathrm{Si}$ was applied. Therefore, reduced growth parameters in phalaenopsis orchid liners observed in both experiments were possibly related to the applied concentration of $\mathrm{Si}$ and the elevated EC value. This indicates that $\mathrm{Si}$ rates of $2.0 \%$ were detrimental to phalaenopsis orchid liners and fertilization rates ranging from $0.5 \%$ to $1.0 \%$ provide the best results in growth parameters. In general, plant growth is reduced as EC levels increase in the substrate (Wootton et al., 1981). Judd and Cox (1992) reported that high substrate EC inhibited growth and re- duced dry weight in new guinea impatiens (Impatiens hawkeri). In phalaenopsis, Wang (1998) indicated that high EC promoted larger total leaf area and increased flower number. However, smaller flowers and root injury were observed. Furthermore, shoot FW was reduced at the highest EC, thus agreeing with the results in this study.

The data obtained from both experiments show that phalaenopsis orchid liners are accumulators of Si. The $\mathrm{Si}$ concentrations in phalaenopsis orchid leaf tissues increased three- to 10 -fold as $\mathrm{Si}$ application rates increased as compared with control, thus confirming that phalaenopsis orchid liners are $\mathrm{Si}$ accumulators and responsive to Si fertilization. The increase in Si content in phalaenopsis orchid tissues may be the result of an active transport mechanism for $\mathrm{Si}$ uptake. We raise this hypothesis based on previous studies as reported by Chen et al. (2001) who demonstrated that foliage plant roots absorb Si from the substrate and translocate a greater fraction of $\mathrm{Si}$ to shoots, resulting in $\mathrm{Si}$ accumulation. Furthermore, associated with $\mathrm{Si}$ accumulation, Si uptake has been reported to be faster than water in some grasses (Gramineae), and an active transport mechanism for Si uptake has been identified, characterized, and described ( $\mathrm{Ma}$ et al., 2006). Such active uptake mechanism has resulted in a threefold Si content increase in tissues of grasses, therefore providing support to our hypothesis.

To our knowledge, this is the first study using $\mathrm{Si}$ fertilization in a commercial orchid nursery demonstrating phalaenopsis orchid liners are $\mathrm{Si}$ accumulators with a potential active uptake system. Follow-up studies should examine how Si affects phalaenopsis orchids throughout its

Table 1. Effect of silicon (Si) applied as potassium silicate on percent silicon (Si) leaf tissue content and plant growth parameters of phalaenopsis orchid liners. ${ }^{\mathrm{z}}$

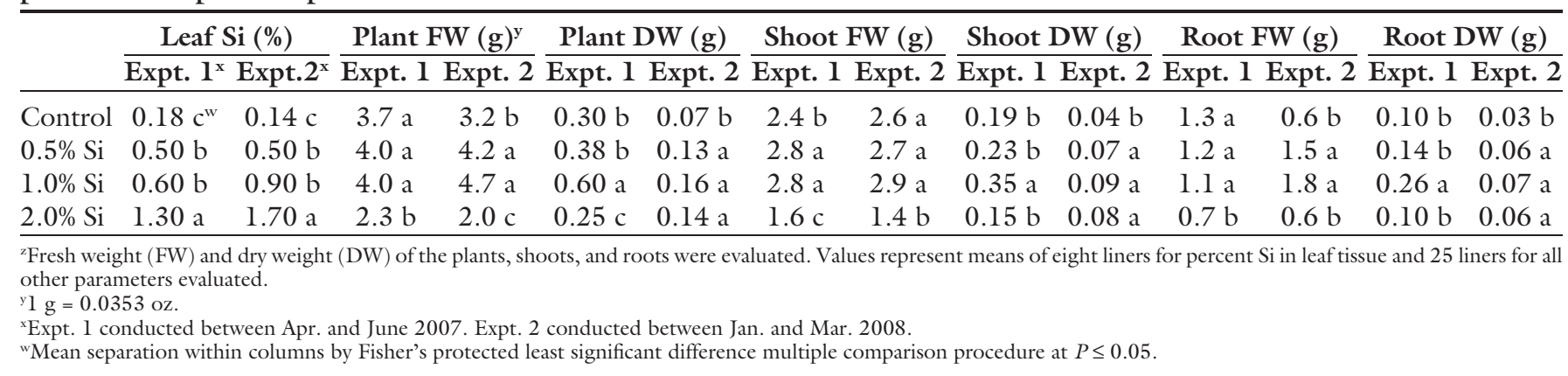



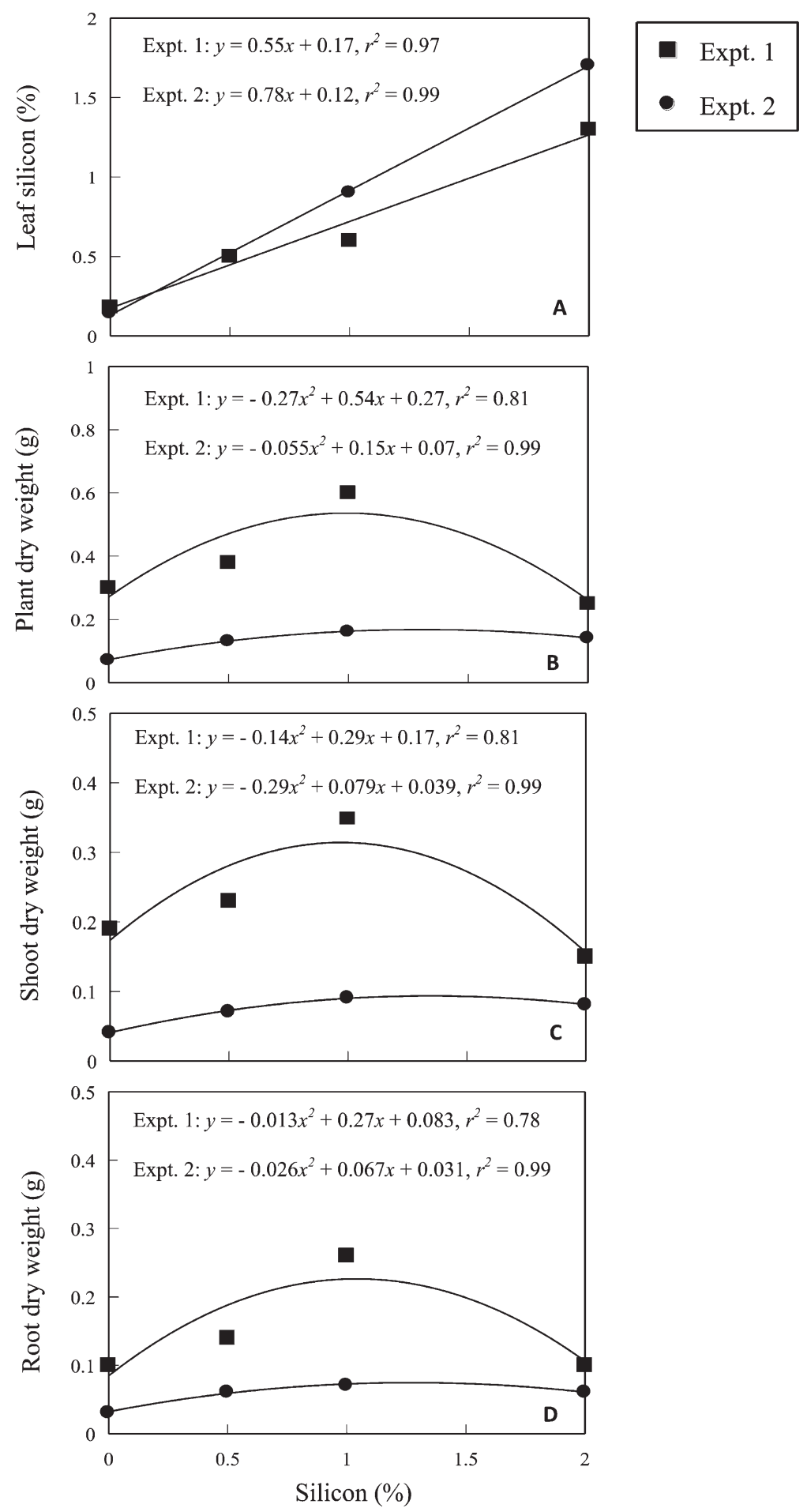

Fig. 1. Effects of silicon ( $\mathrm{Si}$ ) fertilization on phalaenopsis orchid liners supplemented with $0.5 \%, 1.0 \%$, and $2.0 \% \mathrm{Si}$. (A) Si content in leaves. The line represents the relationship between $\mathrm{Si}$ concentration in leaves of phalaenopsis orchid liners $(y)$ and concentration of $\mathrm{Si}(x)$ applied. (B) Plant dry weight (DW), (C) shoot DW, and (D) root DW. The curves represent the relationship between plant DW, shoot DW, and root DW of phalaenopsis orchid liners $(y)$ and concentration of $\mathrm{Si}(x)$ applied, respectively. Each measurement represents means of eight liners for Si content in leaves and 25 liners for plant, shoot, and root DW; $1 \mathrm{~g}=0.0353 \mathrm{oz}$.

complete life cycle, especially because important horticultural traits such as plant growth rate, size, flower initiation, development, and quality might be enhanced by the uptake of Si. Phalaenopsis orchid liners amended with $\mathrm{Si}$ also showed thicker leaves, possibly as a result of cell wall reinforcement by $\mathrm{Si}$, which could confer plant protection, as discussed by Epstein (1999). Therefore, additional studies on the effects of $\mathrm{Si}$ fertilization on reducing abiotic (i.e., temperature, light, and edema) and biotic (i.e., plant disease) stresses are warranted because of the potential positive impact for the orchid industry.

\section{Literature cited}

Adatia, M.H. and R.T. Besford. 1986. The effects of silicon on cucumber plants grown in recirculating nutrient solution. Ann. Bot. (Lond.) 58:343-351.

Chen, J., R.D. Caldwell, C.A. Robinson, and R. Steinkamp. 2000a. Silicon: The estranged medium element. Environ. Hort. Dept., Florida Coop. Ext. Serv., Inst. Food Agr. Sci., Univ. Florida. Bul. 341.

Chen, J., R.D. Caldwell, C.A. Robinson, and R. Steinkamp. 2000b. Let's put the Si back into soil-Part I. Greenhouse Product News 10:48-51.

Chen, J., R.D. Caldwell, C.A. Robinson, and R. Steinkamp. 2000c. Differential responses of container-grown ornamental foliage plants to silicon application. HortScience 35:458(abstr.).

Chen, J., R.D. Cladwell, C.A. Robinson, and R. Steinkamp. 2001. Let's put the Si back into soil-Part II. Greenhouse Product News 11:44-47.

Datnoff, L.E., G.H. Snyder, and G.H. Korndorfer (eds.). 2001. Silicon in agriculture. Studies in plant sciences, 8 . Elsevier Science, Amsterdam, The Netherlands.

Elliott, C.L. and G.H. Snyder. 1991. Autoclave induced digestion for the colorimetric determination of silicon in rice straw. J. Agr. Food Chem. 39:11181119.

Epstein, E. 1999. Silicon. Annu. Rev. Plant Physiol. Plant Mol. Biol. 50:641-664.

Judd, L.K. and D.A. Cox. 1992. Growth of new guinea impatiens inhibited by high growth-medium electrical conductivity. HortScience 27:1193-1194.

Kamenidou, S., T.J. Cavins, and S. Marek. 2008. Silicon supplements affect horticultural traits of greenhouse-produced ornamental sunflowers. HortScience 43:236239.

Kamenidou, S., T.J. Cavins, and S. Marek. 2010. Silicon supplements affect floricultural quality traits and elemental nutrient concentrations of greenhouse produced gerbera. Scientia Hort. 123:390-394. 
Lux, A., M. Luxova, T. Hattori, S. Inanaga, and Y. Sugimoto. 2002. Silicification in sorghum (Sorghum bicolor) cultivars with different drought tolerance. Physiol. Plant. 115:87-92.

Ma, J.F. and E. Takahashi. 2002. Soil, fertilizer, and plant silicon research in Japan. Elsevier, Amsterdam, The Netherlands.

Ma, J.F., Y. Miyake, and E. Takahashi. 2001. Silicon as a beneficial element for crop plants, p. 17-39. In: L.E. Datnoff, G.H. Snyder, and G.H. Korndörfer (eds.). Silicon in agriculture. Studies in plant sciences, 8. Elsevier, Amsterdam, The Netherlands.

Ma, J.F., K. Tamai, N. Yamaji, N. Mitani, S. Konishi, M. Katsuhara, M. Ishiguro, Y. Murata, and M. Yano. 2006. A silicon transporter in rice. Nature 440:688-691.

Martin, K.P. and J. Madassery. 2006. Rapid in vitro propagation of Dendrobium hybrids through direct shoot formation from foliar explants, and protocorm-like bodies. Scientia Hort. 108:95-99.

Mattson, N.S. and W.R. Leatherwood. 2010. Potassium silicate drenches increase leaf silicon content and affect morphological traits of several floriculture crops grown in a peat-based substrate. HortScience 45:43-47.

Muir, S., C. Khoo, B.K. McCabe, G. Fensom, C. Offord, J. Brien, and B. Summerell. 1999. Some effects of silicon in potting mixes on growth and protection of plants against fungal diseases, p. 374 (abstr.). In: L.E. Datnoff, G.H. Snyder, and G.H. Korndörfer (eds.). Silicon in agriculture. Studies in plant sciences, 8. Elsevier, Amsterdam, The Netherlands.

Neumann, D. and U. zur Nieden. 2001. Silicon and heavy metal tolerance of higher plants. Phytochemistry 56:685692.

Raven, J.A. 2003. Cycling silicon-The role of accumulation in plants. New Phytol. 158:419-421.

Richmond, K.E. and M. Sussman. 2003. Got silicon? The non-essential beneficial plant nutrient. Curr. Opin. Plant Biol. 6:268-272.

Savvas, D., G. Manos, A. Kotsiras, and S. Souvaliotis. 2002. Effects of silicon and nutrient-induced salinity on yield, flower quality and nutrient uptake of gerbera grown on a closed hydroponic system. J. Appl. Bot. 76:153-158.
Snyder, G.H. 1991. Development of a silicon test for histosol-grown rice. Univ. Florida. Belle Glade East Everglades Res. Educ. Ctr. Res. Rpt. EV 1991-2:29-39.

U.S. Department of Agriculture. 2005. Floriculture crops-2004 summary. U.S. Dept. Agr., Natl. Agr. Stat. Serv., Washington, DC.

U.S. Department of Agriculture. 2006. Floriculture and nursery crops situation and outlook yearbook. U.S. Dept. Agr., Econ. Res. Serv., Washington, DC.

Vereniging van Bloemenveilingen in Nederland. 2007. Annual report 2006. Assn. Dutch Flower Auctions, Leiden, The Netherlands.

Wang, Y.-T. 1998. Impact of salinity and media on growth and flowering of a hybrid Phalaenopsis orchid. HortScience 33:247-250.

Wootton, R.D., F.R. Gouin, and F.C. Stark. 1981. Composted digested sludge as a medium for growing flowering annuals. J. Amer. Soc. Hort. Sci. 106:4649.

Zhou, T. 1995. The detection of the accumulation of silicon in phalaenopsis (Orchidaceae). Ann. Bot. (Lond.) 75: 605-607. 